\title{
KONDISI TERUMBU KARANG DI PULAU SALAWATI KABUPATEN RAJA AMPAT PAPUA BARAT
}

\author{
(Condition of Coral Reef at Salawati Island Raja Ampat West Papua)
}

\section{Bonnke P. Sagai ${ }^{{ }^{\star}}$, Kakaskasen A. Roeroe ${ }^{1}$, Indri S. Menembu ${ }^{1}$}

1. Program Studi Ilmu Kelautan, Fakultas Perikanan dan IImu Kelautan, Universitas Sam Ratulangi, Manado.

*e-mail : bonnke_sagai@yahoo.com

The coral reef is a shallow marine ecosystems in the tropics, where the major constituent element of coral, with a variety of other organisms that live in association therein. Natural phenomena and various anthropogenic activities threaten the health and existence of coral reefs. Data collection was done by UPT (Underwater Photo Transect) method was done by underwater photo shoot using a shielded digital camera (housing). Image analysis used software tools CPCe (Coral Point Count with Excel extensions). Results of the assesment of health condition of coral reefs in the three stations at Salawati, obtained by the average value of live coral cover by $25.30 \%$ and in medium category. Cover each coral reefs were the following stations, Station $155.13 \%$ included in either category, Station $215.80 \%$ included in the category of bad, and Station $318.20 \%$ is included in kategoti bad.

Keywords: Coral Reefs, Condition, Under Water Photo Transect.

Terumbu karang adalah suatu ekosistem di laut dangkal tropis, di mana unsur penyusun utamanya karang batu, dengan berbagai biota lainnya yang hidup berasosiasi di dalamnya. Fenomena alam dan berbagai kegiatan antropogenik mengancam kesehatan maupun keberadaan terumbu karang. Pengambilan data dilakukan dengan metode UPT (Underwater Photo Transect) atau Transek Foto Bawah Air dilakukan dengan pemotretan bawah air menggunakan kamera digital yang diberi pelindung (housing). Analisis gambar dengan menggunakan piranti software CPCe (Coral Point Count with Excel extensions). Hasil penilaian kondisi kesehatan terumbu karang ditiga Stasiun di Pulau Salawati, tutupan terumbu karang di setiap Stasiun adalah sebagai berikut, Stasiun $155,13 \%$ termasuk dalam kategori baik, Stasiun 2 15,80\% termasuk dalam kategori buruk, dan Stasiun 3 18,20\% termasuk dalam kategoti buruk.

Kata kunci: Terumbu Karang, Kondisi, Transek Foto Bawah Air.

\section{PENDAHULUAN}

Keanekaragaman hayati pesisir dan lautan Indonesia hadir dalam bentuk ekosistem terumbu karang, ekosistem mangrove, ekosistem padang lamun, ekosistem estuari, ekosistem laut terbuka. Berbagai ekosistem tersebut saling berhubungan secara sinergis melalui aliran arus air dan migrasi biota (Dahuri, 2003).

Di laut tropis, pada daerah neritik, terdapat suatu komunitas yang khusus yang terdiri dari karang batu dan organisme-organisme lainnya.
Komunitas ini disebut terumbu karang. Daerah komunitas ini masih dapat ditembus cahaya matahari sehingga fotosintesis dapat berlangsung (Asriani dan Yuliana, 2012).

$\mathrm{Di}$ daerah tropis hingga subtropis yaitu di antara 320 LU dan 320 LS mengelilingi bumi. Garis lintang tersebut merupakan batas maksimum di mana karang masih dapat tumbuh. Karang pembentuk terumbu hanya dapat tumbuh dengan baik pada daerah-daerah tertentu seperti pulaupulau yang sedikit mengalami proses 
sedimentasi atau di sebelah barat dari benua yang umumnya tidak terpengaruh oleh adanya arus dingin yang berasal dari kutub selatan (Suharsono, 2008).

Karang tumbuh dengan baik di daerah Indo-Pasifik hingga mencapai kurang lebih 80 famili. Faktor alami yang menyebabkan karang dapat tumbuh dengan baik di Indo-Pasifik barat. Sebaran karang tidak hanya terbatas secara horizontal akan tetapi juga terbatas secara vertikal dengan faktor kedalaman. Pertumbuhan, penutupan dan kecepatan tumbuh karang berkurang secara eksponensial dengan kedalaman. Faktor utama yang mempengaruhi sebaran vertikal adalah intensitas cahaya, oksigen, suhu dan kecerahan air (Suharsono, 2008). Kabupaten Raja Ampat merupakan hasil pemekaran dari Kabupaten Sorong dan termasuk salah satu dari 14 kabupaten baru di Tanah Papua. Saat ini, Kabupaten Raja Ampat merupakan bagian dari Provinsi Papua Barat yang terdiri dari 4 pulau besar yaitu Pulau Waigeo, Batanta, Salawati dan Misool. Luas Wilayah Kepulauan Raja Ampat adalah $46.108 \mathrm{~km}^{2}$, terbagi menjadi 10 distrik, 86 kampung, dan 4 dusun. Sebagai wilayah kepulauan, daerah ini memiliki sekitar 610 pulau, atoll dan taka dengan panjang garis pantai $4.860 \mathrm{~km}$, dengan 34 pulau yang berpenghuni. Secara geografis, Raja Ampat berada pada koordinat $2^{0} 25^{\prime} \mathrm{LU}$ $4^{0} 25^{\prime}$ LS dan $130^{\circ}-132^{\circ} 55^{\prime} \mathrm{BT}$ (Mambrisaw, dkk. 2006).

Ekosistem terumbu karang di Kepulauan Raja Ampat terbentang di paparan dangkal di hampir semua pulau-pulau. Pada beberapa bagian terdapat gosong (sand backs) yang juga memiliki terumbu karang di sekelilingnya. Tipe terumbu yang terdapat di Kepulauan Raja Ampat umumnya berupa karang tepi (fringing reef), dengan kemiringan yang cukup curam. Selain itu terdapat juga tipe terumbu cincin (atol) dan terumbu penghalang (barrier reef). Kepulauan Raja Ampat memiliki terumbu karang yang indah dan sangat kaya akan berbagai jenis ikan dan moluska. Berdasarkan hasil penelitian tercatat 537 jenis karang keras $(\mathrm{Cl}$, TNCWWF), 9 diantaranya adalah jenis baru dan 13 jenis endemik. Jumlah ini merupakan $75 \%$ dari jumlah karang di dunia. Tercatat juga 828 (Cl) dan 899 (TNC-WWF) jenis ikan karang sehingga Raja Ampat diketahui mempunyai 1.104 jenis ikan yang terdiri dari 91 famili (Mambrisaw, dkk. 2006). Terumbu karang memiliki berbagai peran penting, baik secara ekologi maupun ekonomi. Di Indonesia terumbu karang memiliki potensi sangat besar, yaitu sebagai berikut:

a) Pelindung ekosistem pantai: Terumbu karang akan menahan dan mencagah energy gelombang sehingga mencegah terjadinya abrasi dan kerusakan di sekitarnya (McAdoo dkk. 2008).

b) Rumah bagi berbagi jenis mahluk hidup di laut: Terumbu karang bagaikan oase di padang pasir untuk lautan, karena banyak hewan dan tanaman yang berkumpul disini untuk mencari makan, memijah, membesarkan anaknya, dan belindung. Bagi manusia, ini artinya terumbu karang mempunyai potensi perikanan yang sangat besar, baik untuk sumber makanan maupun mata pencarian mereka (Barnes dan Hughes, 1999).

c) Sumber obat-obatan: pada terumbu karang banyak terdapat bahan-bahan kimia yang diperkirakan bisa menjadi obat bagi manusia. Saat ini penelitian mengenai bahan-bahan kimia tersebut dipergunakan untuk mengobati berbagai penyakit manusia (Ghoshal dan Lakshmi, 2004).

d) Objek wisata: terumbu karang yang bagus akan menarik minat wisatawan sehingga menyediakan alternatif pendapatan bagi masyarakat sekitar (Hoegh-Gulderberg, 1999).

e) Daerah penelitian : Penelitian akan menghasilkan informasi penting 
dan akurat sebagai dasar pengelolaan yang lebih baik. Selain itu, masih banyak jenis ikan dan organisme laut serta zat-zat yang terdapat di kawasan terumbu karang yang belum pernah diketahui manusia (Nababan, 2009).

Kerusakan terumbu karang, terutama di Indonesia meningkat secara pesat. Terumbu karang yang masih berkondisi baik hanya sekitar $6,2 \%$. Kerusakan ini menyebabkan meluasnya tekanan pada ekosistem terumbu karang alami. Laju eksploitasi terumbu karang masih tinggi karena buruknya sistem penanganannya (Dahuri, 1999). Tujuan dari penelitian adalah: 1) Menilai kondisi terumbu karang Pulau Salawati, 2) menyiapkan baseline data kondisi terumbu karang Pulau Salawati

\section{METODE PENELITIAN}

\section{Lokasi Penelitian}

Penelitian dilaksanakan di Pulau Salawati Kabupaten Raja Ampat.

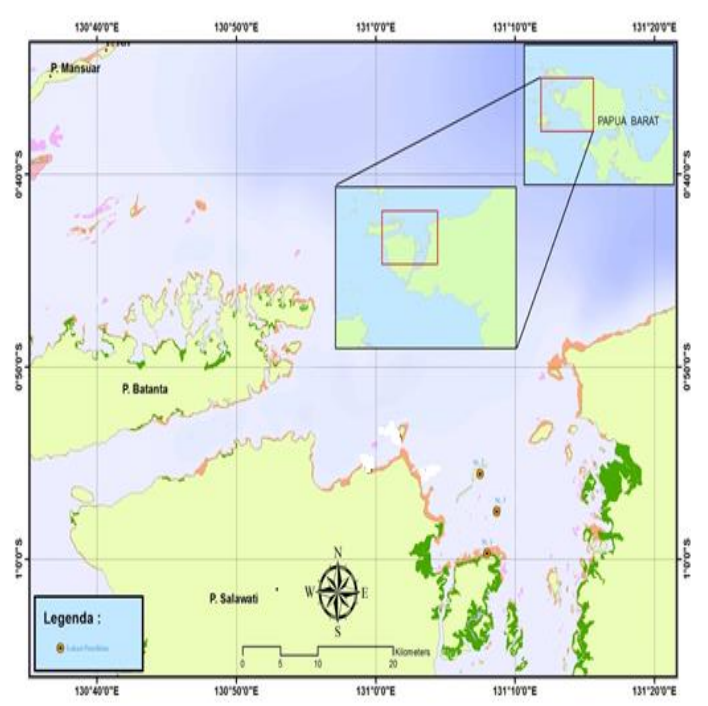

Gambar 1. Peta Stasiun Penelitian
Tabel 1. Titik koordinat

\begin{tabular}{|l|l|l|}
\hline Stasiun & Longitude & Latitude \\
\hline 1. & 131.13312 & -0.99476 \\
\hline 2. & 131.12479 & -0.92609 \\
\hline 3. & 131.14466 & -0.95859 \\
\hline
\end{tabular}

Penggamatan kondisi terumbu karang di Pulau Salawati ditetapkan 3 (tiga) Stasiun yang dapat dilihat pada Peta Stasiun Penelitian (Gambar 1) dan titik koordinat lokasi penelitian yang disajikan pada Tabel 1.

\section{Kategori Terumbu Karang}

karang hategori $\begin{array}{rr}\text { persentase tutupan } \\ \text { didasarkan pada }\end{array}$ Keputusan Menteri Lingkungan Hidup No. 4 tahun 2001 yang disajikan pada Tabel 2.

Tabel 2. Kategori Terumbu Karang

\begin{tabular}{|l|l|l|}
\hline \multicolumn{3}{|c|}{ Ketegori Terumbu Karang (\%) } \\
\hline \multirow{2}{*}{ Rusak } & Buruk & $0-24,9$ \\
\cline { 2 - 3 } & Sedang & $25-44,9$ \\
\hline \multirow{2}{*}{ Baik } & Baik & $50-74,9$ \\
\cline { 2 - 3 } & Baik Sekali & $75-100$ \\
\hline
\end{tabular}

\section{Teknik Pengambilan Data}

Metode Transek poto bawah air (Underwater Photo Transeck= UPT) merupakan metode yang memanfaatkan perkembangan teknologi, baik perkembangan teknologi kamera digital maupun teknologi piranti lunak komputer. Pengambilan data di lapangan hanya berupa foto-foto bawah air yang dilakukan dengan pemotretan menggunakan kamera Canon G-16 yang dilengkapi pelindung tahan air (housing) (Giyanto, dkk. 2014). Fotofoto hasil pemotretan tersebut selanjutnya dianalisis menggunakan piranti lunak Coral Point Count with Excel extensions (CPCe) untuk mendapatkan data yang kuantitatif (Kohler dan Gill, 2006). 


\section{Analisis Data}

Data terumbu karang yang diambil dengan metode UPT merupakan foto-fot bawah air. Setidaknya 50 buah file untuk setiap Stasiun. Data perlu ditangani secara baik dengan cara segera memindahkan file-file yang masih tersimpan dalam memori kamera ke dalam media penyimpanan lain (external harddisk). Hal ini juga berguna untuk keamanan data.

\section{Analisis Foto}

Untuk mendapatkan data-data kuantitatif berdasarkan foto-foto bahwa air yang dihasilkan dari motede UPT ini, analisis data dilakukan terhadap setiap frame dengan cara melakukan pemilihan sampel titik acak. Titik ini digunakan dengan menentukan banyaknya titik acak (random point) yang dipakai untuk menganalisis foto. Jumlah titik acak yang digunakan adalah sebanyak 30 buah untuk setiap framenya, dan ini sudah representative untuk menduga persentase tutupan kategori dan substrat (Giyanto, dkk. 2010). Teknik ini merupakan aplikasi dari penarikan sampel, dimana sebagai populasinya adalah titik-titik yang dipilih secara acak pada foto tersebut. Dengan cara ini, data yang dicatat hanyalah biota dan substrat yang berada tepat pada posisi titik yang telah ditentukan secara acak oleh piranti lunak CPCe.

Berdasarkan proses analisis foto yang dilakukan terhadap setiap frame foto yang dilakukan, maka dapat diperoleh nilai presentase tutupan kategori untuk setiap frame dihitung berdasarkan rumus sebagai berikut:

Persentase tutupan kategori $(\%)=$ (jumlah titik kategori tersebut)

$$
\text { (banyak titik acak) }
$$

\section{HASIL DAN PEMBAHASAN}

\section{Kondisi Terumbu Karang di Stasiun 1}

Kondisi terumbu karang di Stasiun 1 berada pada kategori sedang dengan persentase 45,03\%, 38,09\%, karang mati yang ditutupi alga 2,80\%, karang lunak 5,40\%, Alga 1,93\%, patahan karang $3,94 \%$ dan biota lain selain karang $1,40 \%$.

Dari $45,03 \%$ karang hidup ditemukan 17 genera karang diantaranya adalah Acropora, Anacropora, Asteopora, Echinopora, Montipora, Porites, Pavona, Fungia, Goniastrea, Paraclavarina, Caulastrea, Cosniarea, Mycedium, Symphillia, Turbinaria, Leptoseris, Herpolitha. Namun genus yang dominan adalah genus Porites.

\section{Kondisi Terumbu Karang di Stasiun 2}

Kondisi terumbu karang di Stasiun 2 termasuk dalam kategori buruk persentase karang hidup hanya 9,81\%. Di Stasiun 2 ini yang mendominasi adalah alga dengan persentase tutupan sebesar 36,36\%, patahan karang $17,55 \%$, karang mati $6,60 \%$, pasir $14,08 \%$, karang lunak $4,54 \%$ karang mati yang ditutupi alga $2,47 \%$, sementara persentasi biota lain di luar karang $8,61 \%$.

Di Stasiun 2 hadir 8 genera karang di antaranya adalah Acropora, Asteopora, Montipora, Porites, Pavona, Goniastrea, Turbinaria, Leptrastrea. Di Stasiun 2 ini genus Acropora yang lebih dominan dengan persentase $31,47 \%$, diikuti Porites 27,27\%, Leptrastrea $11,19 \%$, Turbinaria dan Montipora memiliki nilai presentasi yang sama 9,79\% Asteopora, Pavona, dan Goniastrea dengan nilai 3,50\%

\section{Kondisi Terumbu Karang di Stasiun 3}

Kondisi terumbu karang di Stasiun 3 tergolong dalam ketegori buruk karena karang hidup di Stasiun 3 
persentase tutupannya hanya $11,13 \%$ diikuti patahan karang 67,27\%, karang mati $9,93 \%$, karang lunak $6,27 \%$, biota selain karang $1,67 \%$, tutupan pasir $2,60 \%$, alga $0,73 \%$ karang mati yang ditutupi oleh alga $0,27 \%$ dan sponge $0,13 \%$.

Dari $11,13 \%$ persentase tutupan karang hadir 12 genera karang di antaranya adalah Acropora, Anacropora, Montipora, Porites, Pavona, Favia, Goniastrea, Turbinaria, Herpolitha, Leptrastrea, Leptoseris, Paraclavarina. Genus Porites adalah genus dengan persentase dominan $45,1 \%$ sedangkan genus dengan persentase terendah adalah genus Montipora dengan persentase $0,6 \%$.

\section{Indeks Keanekaragaman Genus Karang}

Indeks keanekaragaman genus karang dari Stasiun 1 sampai 3 berkisar antara 1,8 sampai 1,9 menandakan Indeks keanekragaman disemua Stasiun berada pada kriteria sedang. Pada Stasiun 1 nilai indek keanekaragaman adalah 1,9. Pada Stasiun 2 dan Stasiun 3 nilai indek keanekaragaman adalah sama-sama 1,8 .

\section{KESIMPULAN}

1. Dari 3 stasiun pengamatan kondisi terumbu karang di Pulau Salawati, didapatkan dua kategori kondisi terumbu karang, yaitu kondisi sedang dan buruk. Jika dilihat kondisi terumbu karang dari setiap stasiun, didapatkan stasiun 1 berada dalam kategori sedang, stasiun 2 berada dalam kategori buruk, dan stasiun 3 berada dalam kategori buruk.

2. Beseline yang dihasilkan adalah informasi tentang kondisi terumbu karang di pulau Baseline yang dihasilkan adalah informasi tentang kondisi terumbu karang di Pulau Salawati yang kondisi terumbu karangnya berada antar kondisi sedang dan buruk.
Keanekaragaman genus karang di Pulau Salawati yang diwakili dari hasil pengamatan di 3 stasiun didapatkan nilai keanekaragaman $\left(H^{\prime}\right)$ perstasiun termasuk dalam kriteria sedang.

\section{DAFTAR PUSTAKA}

Asriyana, Yuliana. 2012. Produktivitas perairan. Jakarta: Bumi Aksara. Xxii +278 hlm.

Barnes, R.S.K., Hughes, R.N. An introduction to marine ecology $\left(3^{\text {rd }}\right.$ ed). Blackwell Science. 1999.

Dahuri, R. 1999. Kebijakan dan strategi pengelolaan terumbu karang indonesia.

Dahuri, R. 2003. Keanekaragaman Hayati Laut: Aset pembangunan Berkelanjutan Indonesia. PT Gramedia Pustaka Utama. Jakarta. Xxxiii + 412 hal.

Ghoshal, S.H., Lakshmi, V. 2004. In vitro and in vivo activity of extracts from the soft coral Lobophytum pauciflorum on trophozoites of Entamoeba hystolytica. Russian J. Mar. Biol. 30:426-428.

Giyanto, B.H., Iskandar, D., Soedharma, Suharsono. 2010. Effisiensi dan akurasi pada proses analisis foto bawah air untuk menilai kondisi terumbu karang. Oseanologi dan Limnologi di Indonesia 36 (1): 111-130.

Giyanto, A.E., Manuputty, M., Abrar, R.M., Siringoringo, S.R., Suharti, K., Wibowo, I.N., Edrus, U.Y., Arbi, H.A.W., Cappenberg, H.F., Sihaloho, Y.,Tuti, D., Zulfianita. 2014. Panduan Monitoring Kesehatan Terumbu Karang: Terumbu Karang, Ikan Karang, Megabenthos dan 
Penulisan Laporan. Jakarta: COREMAP CTI LIPI.

Hoegh-Gulderberg O. Climate change, coral bleaching and the future of the world's coral reefs. Mar. Freshwater Res. 1999; 50:839866.

Kohler, K.E., Gill, M. 2004. Coral Point Count with excel extensions (CPCe): avisual basic program for the determination of coral and substrate coverage using random point count methodology. Comput Geosci 32(9):1259-1269.

Mambrisaw, .A., Wurlianty, .B., Liuw,.F., Hamel, .S., Lamatenggo, .S., Rumbekwan, .I., Muljadi, A.H., Sukmara, .A., Sumantri, .H., Omkarsba, . J. 2006. Atlas Sumberdaya Pesisir Kabupaten Raja Ampat Provinsi Irian Jaya Barat. Waisai

McAdoo, B.G., Moore, A., Baumwoll, J. Indigenous knowledge and the near field population response during the 207 Solomon Islands tsunami. Nat. Hazards. 2008; DOI 10.1007/s11069-008-9249-

z.

Menteri Negara Lingkungan Hidup. 2001. Lampiran Surat Keputusan Mentri Negara Lingkungan Hidup No. 04 tahun 2001. tentang Kriteria Baku Mutu Kerusakan Terumbu Karang, Jakarta.

Nababan, T.M. 2009. Persen Tutupan (Percent Cover) Terumbu Karang Hidup di Bagian Timur Perairan Pulau Rubiah Nanggroe Aceh Darussalam. Medan. 